\title{
GLOBAL UNIONS
}

Challenging Transnational Capital through Cross-Border Campaigns

EDITED BY

KATE BRONFENBRENNER

ILR Press

AN IMPRINT OF

Cornell University Préss

Ithaca and London 


\section{Copyright @ 2007 by Cornell University}

All rights reserved. Except for brief quotations in a review, this book, or parts thereof, must not be reproduced in any form without permission in writing from the publisher. For information, address Cornell University Press, Sage House, 512 East State Street, Ithaca, New York 14850.

First published 2007 by Cornell University Press First printing, Cornell Paperbacks, 2007

Printed in the United States of America

Library of Congress Cataloging-in-Publication Data Global unions : challenging transnational capital through crossborder campaigns / edited by Kate Bronfenbrenner.

p. cm. - (Frank W. Pierce memorial lectureship and conference series; no. 13)

Papers originally presented at a conference held Feb. 9, 2006 in New York, N. Y.

Includes bibliographical references and index.

ISBN 978-0-8014-4616-0 (cloth : alk. paper) - ISBN 9780-8014-7391-3 (pbk. : alk. paper)

1. International labor activities-Congresses. 2. Labor unions-Congresses. 3. International business enterprisesCongresses. 4. Globalization-Congresses. I. Bronfenbrenner, Kate, 1954- II. Title. III. Series.

\section{HD6475.AIG57 2007}

$331.88091-\mathrm{dc} 22$

Cornell University Press strives to use environmentally responsible suppliers and materials to the fullest extent possible in the publishing of its books. Such materials include vegetable-based, low-VOC inks and acid-free papers that are recycled, totally chlorine-free, or partly composed of nonwood fibers. For further information, visit our website at www.cornellpress.cornell.edu.

Cloth printing 


\section{CONTENTS}

Acknowledgments

Introduction

KATE BRONFENBRENNER

1. Beating Global Capital: A Framework and Method for Union Strategic Corporate Research and Campaigns

TOM JURAVICH

2. "Due Diligence" at APM-Maersk: From Malaysian Industrial Dispute to Danish Cross-Border Campaign

PETER WAD

3. Indian Labor Legislation and Cross-Border Solidarity in Historical Context

ASHWINI SUKTHANKAR AND KEVIN KOLBEN

4. Struggle, Perseverance, and Organization in Sri Lanka's Export Processing Zones

SAMANTHI GUNAWARDANA

5. Organizing in the Banana Sector HENRY FRUNDT

6. Dockers versus the Directives: Battling Port Policy on the European Waterfront 
vili

7. Going National or European? Local Trade Union Politics within Transnational Business Contexts in Europe

VALERIA PULIGNANO

8. Labor-Community Coalitions, Global Union Alliances, and the Potential of SEIU's Global Partnerships

AMANDA TATTERSALL

9. International Framework Agreements: Opportunities and Challenges for Global Unionism

DIMITRIS STEVIS AND TERRY BOSWELL

10. Beyond Workers' Rights: Transnational Corporations,

Human Rights Abuse, and Violent Conflict in the Global South

DARRYN SNELL

Conclusion

KATE BRONFENBRENNER

References

Index 


\title{
INTRODUCTION
}

\author{
KATE BRONFENBRENNER
}

On February 9, 2006, more than 560 representatives from unions, union federations, academia, and nongovernmental organizations (NGOs) from around the world gathered at the Crowne Plaza Hotel in New York City for the "Global Companies-Global Unions-Global Research-Global Campaigns" conference. The overall goal of the conference was to strengthen labor's capacity to conduct more effective strategic corporate research and run more effective comprehensive cross-border campaigns against the world's largest transnational firms. Yet perhaps the theme of the conference was best summed up by AFL-CIO secretary treasurer Richard Trumka in his remarks in the opening plenary:

Brothers and Sisters, I like the theme of this conference because it lays out the challenges before us in almost biblical terms - global companies begat global problems for workers-global problems begat the need for global unions-and if global unions want to truly match the might and power of global corporations we have to undertake global research and global campaigns. (Trumka 2006)

Unions around the world continue to operate in an ever-more complex and rapidly changing corporate environment. Increasingly the employers they face across the bargaining table or in organizing campaigns are part of diffuse transnational companies that have minimal loyalty to any single industry, product, or country. At the same time, never before have the ties between governments and supragovernmental institutions such as the World Trade Organization (WTO), the European Union (EU), or the World Bank been 
more closely integrated with the interests of the world's largest transnational corporations than they are now. In today's environment, large sectors of the public have come to believe that Wal-Mart is unstoppable in leading the pursuit of a worldwide race to the bottom. On this issue there is little difference between workers in North Carolina who watch their jobs move to Mexico and those in Ireland who watch their jobs go to India or in China who lose their jobs to Vietnam (Bronfenbrenner and Luce 2004). They only need look at Oscar-nominated films such as Syriana or The Constant Gardener to find out what happens to those who dare to challenge capital when it is in cahoots with the highest levels of government.

However, this is just one piece of the story. In the real world not every effort to fight back against the forces of global capital ends in devastating defeat. The more than 560 people gathered in New York in February demonstrated that there is a strategic front uniting against the combined power of the neoliberal state and transnational corporations. The labor movement and its allies have done battle with some of the most powerful transnational firms and governments and won. They can do it again, but only if they understand the power structure and vulnerabilities of these new kinds of corporations, the extent of their operations, and the relationships they have with their stakeholders. Equally important, they will succeed only if they build a global labor movement based on equality and respect through cross-border campaigns. It will be critical to involve unions and NGOs locally, nationally, and internationally. The Global Unions Conference and this book, which came out of the conference, address these challenges.

\section{A Historic Perspective}

In 1986, the United Mine Workers of America (UMWA), under the leadership of its new young president, Richard Trumka, joined with the National Union of Mineworkers (NUM), other South African unions, the Free South Africa Movement (FSAM), and the rest of the U.S. labor movement to unleash a worldwide campaign against oil companies operating in South Africa, with Royal Dutch/Shell as the first target of a global boycott (Walker 1986; Multinational Monitor 1986).

Shell was not chosen randomly as the target by either the South African or the U.S. unions. Oil companies were the focus of the boycott because oil was critical to the South African economy; the military and the police, for example, depended on oil to break strikes and crush demonstrations. Having no indigenous supplies of oil to rely on, the South African regime was wholly dependent on the big oil companies for its very survival. Royal Dutch/ Shell in particular stood out as a target because it had continued to ignore 
pressure from the United Nations' voluntary oil embargo to stop supplying oil to South Africa, but also because it had a long history of serious health and safety violations and antiunion actions in its mines and refineries in South Africa (Multinational Monitor 1986; Knight 2001). The fact that two of its coal subsidiaries, Shell SA's Reitspruit and Shell USA's A.T. Massey, had just been involved in two brutal strikes involving the UMWA and NUM provided additional grounds for making Shell a key target (Walker 1986).

The global campaign against Shell was perhaps the most comprehensive and most effective example of cross-border solidarity of Jabor and its allies in history. Unions, antiapartheid groups, churches, civil rights organizations, and social justice NGOs from around the world came together in common cause not out of their own self-interest but to make clear to the world's largest transnational firms that they were going to make the cost of doing business with South Africa prohibitive and the costs to the South African apartheid government even greater. Profits were cut and businesses withdrew. Some corporations, such as Mobil Oil, pulled out quickly; others, such as Shell, endured great costs but never left. But eventually the apartheid government conld no longer withstand the combination of external pressure and escalating action by the black majority inside South Africa. What made the story even more remarkable was that it occurred during the period when much of the world's labor movement was still bitterly divided along cold-war lines. Despite the close ties between the Congress of South African Trade Unions (COSATU), the African National Congress (ANC), and the Communist Party, not only unions such as the UMWA, the United Auto Workers (UAW), and the American Federation of State, County, and Municipal Employees (AFSCME)-allied with TransAfrica and FSAM from early on-but the American Federation of Labor and Congress of Industrial Organizations (AFL-CIO) endorsed the Shell boycott as well (Knight 2001; Walker 1986).

The boycott was active in more than a dozen countries, particularly in Royal Dutch/Shell's home countries of Britain and the Netherlands. While unions in Europe were not enthusiastic about the boycott tactic, most supported antiapartheid sanctions, including the oil embargo, and South Africa's nascent trade union movement in other ways. Seafarers' unions from several countries, for example, provided critical support for the oil embargo by helping to track and to expose the global oil trade with South Africa. The Danish and Norwegian labor movements successfully convinced their governments to impose bans on oil transports and exports to South Africa (Hengeveld and Rodenburg 1995).

There were unionized workers at oil companies in all countries affected, particularly in South Africa, who actively questioned the risks and benefits of the oil boycott (Baskin 1991). These were particularly important lessons to learn: global alliances and the long-term battle against transnational firms have 
short-term costs that affect workers and unions differently in different countries. How to balance interests and identify common goals in this context can be the most difficult challenge for global campaigns.

Without question, workers and their representatives around the world would be living and working in a very different environment if similar stories of coordinated struggles had occurred during the last twenty years. Stopping the collusion of governments and transnational corporations in depriving workers of fundamental political, social, and economic rights has become harder today because, unfortunately, labor did not learn this lesson from its involvement in the South Africa divestment campaign. Instead of being emboldened to challenge global capital and construct a more united, progressive, and internationalist vision, in most cases organizations returned to their own struggles. Periodically one or another group asked for support in their individual contract or organizing struggles with employers, and different organizations stepped forward. The support, however, was sporadic and temporary. Some of those battles reached a truly global scale, such as the Steelworkers' struggle against Bridgestone Firestone to keep their union and hold on to pattern bargaining in the rubber industry, which ultimately involved solidarity actions in eightythree countries (Juravich and Bronfenbrenner 2003). Another example was the successful campaign to organize 1,200 workers at Gina Bra Form Company in Thailand, which won support from the National Human Rights Commission of Thailand and from more than a dozen international union organizations, labor NGOs, and consumer and student solidarity organizations from around the globe (Robertson and Plaiyoowong 2004).

Yet twenty years after the global labor movement launched its boycott against Royal Dutch/Shell, the world's largest corporations wield more power and are more globally connected and less fettered by global union solidarity than they were in 1986. Now the challenges are greater. Where before transnational corporations seemed at least somewhat bounded by loyalty to product, firm, industry, or country, today the largest of these firms increasingly supersede most government authority and are constrained only by the interests of their biggest investors, lenders, and shareholders.

For too long most union members and their leaders tended to see their collective bargaining environment as truly limited by the national boundaries of their own labor laws and the interests of their dues-paying members. Even as more of the employers they dealt with became foreign-owned or had foreign operations, and as nearly every industry in every part of the world was faced with having jobs outsourced from higher-wage countries to lowerwage countries, unions continued to think of themselves as part of a national, not international, labor movement. There were noteworthy exceptions. In some cases, such as Ravenswood Aluminum Corporation or Chunghwa Telecom, these were defensive actions, in which local unions, with the help 
of national unions, global union federations (GUFs), and local, national, and international NGOs, mounted global campaigns to save the members' jobs and in many cases the union itself (Juravich and Bronfenbrenner 1999; Chang 2006).

In contrast, other organizations have moved aggressively to build alliances as part of organizing campaigns. These include the AFL-CIO, Teamsters, and Union Network International (UNI), which supported a global campaign to organize workers at Quebecor in the United States, Europe, and Latin America (Trumka 2006; Brecher, Costello, and Smith 2006); the global organizing campaigns at Nestlé and Coca-Cola by the International Union of Food, Agricultural, Hotel, Restaurant, Catering, Tobacco and Allied Workers' Associations (IUF) (Garver et al. 2006); and UNITE HERE's campaign to organize PinaultPrintemps-Redoute (PPR) subsidiary Brylane (Clean Clothes Campaign 2002). But these campaigns have been few and far between. The greater capital's capacity to increase the power and speed with which it restructured its organization, the more difficult it was for labor to find its bearings. In the words of Hassan Yussuff from the Canadian Labor Congress, labor struggled to "match the other side's speed and mobility and capacity to change" (Yussuff 2006).

\section{Global Unions Conference}

In recent years there have been many in both the labor movement and academia who have been thinking and strategizing on just how labor can best meet the challenge it faces in organizing and bargaining with the world's largest and most powerful transnational corporations. Starting in the fall of 2002 a group of union leaders, union researchers and strategic campaigners, and labor scholars, led by Richard Trumka, now secretary treasurer of the AFLCIO; Bruce Raynor, president of UNITE HERE; Ron Blackwell, director of corporate affairs, AFL-CIO; and Kate Bronfenbrenner, Cornell ILR, came together to begin discussing these issues. This collaboration led to the Global Unions Conference in 2006. From the beginning its primary mission focused on improving labor's capacity to take on the world's largest transnational corporations and shift global economic and political power back into the hands of workers and communities. The framework for our initial discussions grew from the following assumptions.

First, there continued to be a severe shortage of individuals in the United States and around the world who were trained in strategic corporate research. Even those who were conducting research tended to use a simplistic model that failed to capture the complex and diffuse nature of corporate structure and ownership among the world's largest transnational employers. We now have developed a model for teaching strategic corporate research that better 
captures the complex and changing character of these firms. The challenge, however, was how we could best disseminate our model to the widest audience possible.

Second, most unions were not researching the employer they were dealing with in organizing or bargaining campaigns. While some industrial unions had run noteworthy cross-border campaigns when confronted with aggressive employer opposition at the bargaining table, such campaigns were rare in the organizing context and infrequent in the bargaining context, and were almost always defensive in nature.

Third, even those campaigns that did exist were too often unilateral in nature, with the expectation that unions in other countries would come to the rescue of U.S. unions faced with tough foreign-owned transnational firms. U.S.-initiated campaigns to support organizing and bargaining by unions and workers in other countries were much less common. This problem was not limited to the United States. Unions engaged in struggles with employers in the United Kingdom, Canada, Australia, and, to a lesser degree, western Europe, sought help from workers in the Global South or eastern Europe but did not reciprocate.

Another critical tension developed among some unions in Europe over whether the comprehensive campaign model interfered with their own positive relationships with employers. At the same time, others in Europe wanted to link more with unions in North America and the Global South in these campaigns as they watched the same employers that had been battling unions in North America begin to move toward privatization and shifting of union work out of western Europe toward eastern Europe and the Global South. Unions in the Global South continued to raise the question of how much workers in the Global North understood that their lifestyle and living standards depended on the continued degradation of living standards and environmental conditions in the South.

Finally, there was an extreme shortage of quality academic research relating to all aspects of these questions, from the changing nature of corporate ownership structure and practices of the world's largest transnational firms to the extent and effectiveness of union responses to these changes in the structure and power of global capital.

With these concerns in mind, the initial planning group reached out to the larger labor and academic community around the world in order to move forward with the planning process. In February 2006 this collaboration bore fruit, when the conference opened to a standing-room-only crowd, with registrants from fifty-three countries and six continents. The majority of the participants were from outside the United States, and more than seventy came from the Global South, including fifty-seven whose travel was funded by contributions from unions, universities, and NGOs supporting the conference. 
Representatives from every GUF and many national trade union federations were in attendance.

The conference also featured strategic research on ten key transnational corporations from diverse sectors and industries such as Wal-Mart, Alcoa, Starwood, Exxon Mobil, Kraft, and Sanofi-Aventis. These companies were the focus for discussions of both a strategic analysis of the structure and flow of corporate power within each company and how best to build and strengthen lasting cross-border networks among unions, scholars, and NGOs working with these target multinationals.

One of the most important aspects of the conference was the effort made to ensure representation from the Global South for all ten target firms and the connections that resulted from that effort between trade unionists from Europe and North America and trade unionists from Asia, Africa, and Latin America from the same company. However, this coming together of participants from the Global North and Global South was not limited to the target company sessions alone. It was a common thread in every part of the conference, from the plenary sessions to the workshops and panel presentations. In fact, this may have been the single most significant accomplishment of the conference and part of what made it such a historic event. In a time when global outsourcing has led too many workers and their unions to complain that seemingly undeserving workers in the Global South are stealing jobs that "rightfully" belong in North America or western Europe, this was one space where the framework for that debate had shifted to a common understanding that this was not a U.S. problem or a European problem but a global labor problem that could be solved only through a united effort.

The large number of participants from unions from Europe and the full support from the GUFs also represented a significant change in the perception of where the European labor movement and GUFs stood on the issue of comprehensive cross-border campaigns. In fact, the sessions were filled with stories of unions in Europe beginning to link with one another and with unions in other countries, as employers with whom they had heretofore had a stable labor relationship were now engaging in large-scale cutbacks in jobs and demands for concessions in wages and social benefits.

Representatives from every country denounced the growing power of neoliberal governments in the economic, political, environmental, and military arena and their oppressive impacts on workers, sacrificing their economic and democratic rights in the name of global capital. As Bertha Lujan, former national coordinator of Mexico's Authentic Labor Front (FAT), argued in her plenary speech, political struggles against neoliberal governments, such as the recent victory in Bolivia, are of equal importance in challenging capital.

We need an ideological campaign so that we can be victorious over those who have power over us, and we can then become organized only in so far as 
our organizations are strengthened, and each one of us needs to contribute our grain of sand so that we can have a new world at home, at our workplace, in our country, in the world. (Lujan 2006)

Organizing the conference involved surmounting enormous hurdles-financial, geographic, and political. In fact from planning to fruition it would take four years. It was a historic event, not just because 560 trade unionists and academics came together to talk about how to take on global capital but specifically because of who was in the room. From around the world the people gathered there were representatives from unions, academia, and NGOs who were actively involved in either researching or conducting cross-border campaigns with the world's largest transnational firms, a group that had never gathered in one place before. The conference, both inside and outside the formal sessions, focused on a chance to share strategies, make connections, learn from one another, and build lasting networks for the future. For the three days of the conference the divisions that fell by the wayside were the split in the U.S. labor movement, the tensions over GUF protocols, and old cold-war legacies about which unions should be invited to the table. It felt as if a global labor movement was indeed possible.

\section{Compiling This Book}

The conference planners believed that one of the ways that trade unionists and academics were going to gain an objective understanding of how to best strengthen labor's capacity to mount more strategic, comprehensive, and effective cross-border campaigns was to generate more high-quality research on labor's efforts to date-both successful and unsuccessful-at running cross-border campaigns with transnational firms. Thus part of the conference-organizing process was a call for papers, sent out in English, French, and Spanish to scholars and trade unionists all over the world. The best papers would be published by Cornell University Press as part of an edited book.

More than ninety-six paper proposals were submitted, and of those, fiftyone were accepted for the conference. The subjects ranged from critical debates on the role of IFAs to tactical questions on the use of the Internet in cross-border campaigns, as well as analyses of cross-border campaigns in specific industries such as logistics, auto, bananas, or the retail sector or in specific countries such as Thailand, India, or China. Prior to the conference, the literature on global unions consisted of a handful of books and articles. By the end of the conference, for the first time, there was a body of original research relating to global comprehensive cross-border campaigns. 
As editor, my challenge was to put together a book that would do the best job of moving forward the goals and themes upon which the conference was based. That meant, first of all, presenting the model of strategic corporate research and comprehensive campaigns that had provided the theoretical framework for the entire conference. Second, the collection would need to capture the challenges of running comprehensive cross-border campaigns in the current global environment as well as the range of innovative strategies that unions have attempted to use to adapt to different circumstances, industries, countries, and corporations. Finally the chapters had to communicate the global character of comprehensive cross-border organizing and bargaining campaigns. My goal was a book that included original research from scholars around the world on cross-border campaigns involving different companies, industries, regions, and sectors that took place, for the most part, outside the United States.

The book starts with a chapter by Tom Juravich that describes the evolution of the theoretical framework and model for strategic corporate research and comprehensive campaigns upon which the conference was based (and the model that was used to prepare the research reports on the ten target companies for the conference). Juravich not only provides a detailed road map for understanding how power flows in the more diffuse and complex structures that dominate the transnational landscape today but also lays out a framework for moving from research to a critique of the company and identifying profit centers, growth strategies, decision makers, and the key relationships that then become the multiple points of leverage upon which comprehensive campaigns are built.

The nine chapters that follow provide a cross section of examples of comprehensive cross-border campaigns in different kinds of industries, corporations, regions, and circumstances. Each is distinct because each campaign was entirely different from all the others, with no overlap in either company or union characteristics or in industry. Yet in combination they provide a full picture of the range of strategic responses that unions are using in trying to develop a more global response to a complex world economy. The common thread for each of the campaigns is that in each case the unions involved had to tailor their campaign to adjust to the unique environment in which they were operating.

The first three chapters cover three very different campaigns in Asia-workers in a medical supply company in Malaysia, Unilever workers in India, and women apparel workers in Sri Lanka. In chapter 2, Peter Wad tells the story of how the workers at a Malaysia medical supply company were able to organize a union in their factory through an alliance with a Danish NGO that was dominated by the Danish labor movement rather than through the expected route of using pressure from the unionized workers at the heavily unionized company headquarters of APM-Maersk in Denmark. This example not only 
captures the largely untold story of links between unions organizing in the Global South and unions in Europe but also demonstrates how the model presented in chapter 1 will require the development of a unique strategy depending on the differing vulnerabilities of the company, and how alliances with other stakeholders can best be utilized in exerting pressure on the firm.

The challenge of alliance building between unions in the Global South and those in the Global North is given some historical context by Ashwini Sukthankar and Kevin Kolben in chapter 3. They remind us that even in the earliest days of colonial India, labor struggles had a cross-border consciousness. Workers in India protested issues such as the establishment of a subcontracting employment system because it led to absent and unaccountable employers. More currently, as they argue in their two case studies of Unilever subsidiaries, cross-border campaigns are most effective when the strategies are largely shaped by the issues and interests of Indian unions and consumers rather than decided top down by northern unions and NGOs. Only then can they overcome the negative legacy of job protectionism from Europe and North America and the sense among many Indian trade unionists that the emphasis of northern unions and NGOs on corporate social responsibility often ends up being offered as an alternative to unionization.

Using data collected through participant observation research while she worked as an apparel worker in an export processing zone (EPZ) apparel factory in Sri Lanka for eleven months in 2003, Samanthi Gunawardana tells, in the voices of the workers themselves, how even in the most hostile of environments, workers can and do organize through cross-border comprehensive campaigns (chapter 4). Victory did not come easily but in stages. First, women-to-women networks grew out of the women's common identity as EPZ workers and the multiple problems they faced in the workplace and in their living situation. Then the women began coalition building with local NGOs, which was then followed step by step by national and international labor and NGOs from around the world. Gunawardana argues that in this kind of environment these worker-to-worker networks, nationally and internationally, are necessary for success. Given that between 2003 and 2006 the number of unionized workers in the Sri Lankan EPZs grew from six thousand to fourteen thousand, this appears to be a strategy worth heeding.

The book then switches gears by moving to a campaign on a very different scale in the banana sector in Latin America and the Caribbean. Here Henry Frundt presents union comprehensive campaigns at a much more advanced level. He explains how the banana unions used a combination of cross-border strategies to increase or rebuild union density and strengthen bargaining power, not just in one company in one country but in multiple transnational firms throughout the banana sector in Latin America and the Caribbean (chapter 5). As Frundt describes, not only did the banana unions utilize multiple 
coalitions with small farmer associations, European and North American NGOs, and the IUF, but they also employed a diversity of strategies. These ranged from directly negotiating with transnational banana firms for both local contracts and IFAs to challenging international trade policies that adversely impact banana workers. The banana unions have also worked to establish independent certification programs and Fair Trade Labeling programs that recognize organizing and collective bargaining rights as well as social and environmental standards.

The next three chapters focus on three campaigns in Europe involving dockworkers and General Motors workers Europe-wide, and the Service Employees International Union (SEIU)-Transport and General Workers Union(T\&G) campaign with school bus drivers in the United Kingdom. The dockworkers, or dockers, the focus of Peter Turnbull's research in chapter 6, may have one of the longest traditions of cross-border solidarity of any industry, since international linkages are a natural outgrowth of the work process in marine shipping. However, Turnbull's research focuses on cross-border campaigns strictly within the EU context-namely, the response of European dockers to directives issued by the European Commission in 2001 and 2006, both of which seriously threatened job security, social benefits, and union power on the docks across Europe. In what would be called the "war on Europe's waterfront," docker unions and the International Transport Federation (ITF) launched a campaign of demonstrations, strikes, and coordinated workplace education and action across Europe to get the first directive voted down in an unexpected victory for the dockers in 2003 . This was followed by a more nuanced but equally successful campaign of lobbying and legislative action in 2004-6 backed up by the threat of the capacity to strike. As Turnbull explains, the European dockers' story is a lesson in how unions can adapt to the changing political and economic environment, in this case the EU, by developing new "repertoires of contention" to tilt the balance of power away from transnational capital.

Valeria Pulignano provides a critical analysis of how the European Metal Workers' Federation, absent any historical tradition of cross-border bargaining or organizing, worked to coordinate workplace and community actions across borders throughout Europe in response to the recent wave of corporate restructuring and threats of plant closings, job loss, and cutbacks in wages and benefits at GM and its subsidiaries (chapter 7). She describes how unions were able to coordinate activity across borders to restrain, but not prevent, GM from forcing locals and regions to compete against each other to save jobs in their communities. Pulignano argues that the GM case suggests that union bargaining power in a restructured Europe depends on moving from national to European bargaining structures and coupling this process with constant communication and linkages across borders at every level of the trade union movement. 
Amanda Tattersall explores the challenges and possibilities of attempting cross-border alliances in the service sector through her analysis of SEIU's global partnerships unit and the Driving Up Standards campaign between SEIU and the T\&G in the United Kingdom from 2004 to 2006. Chapter 8 explores the structural innovation of the global partnerships unit and draws out the possibilities and difficulties for this form of global union collaboration. Tattersall notes the strengths of the campaign-its success in global coalition building to stop employers in the United Kingdom and Europe from treating their U.S. employees and unions differently than they treat those in their headquarters countries. She also points out that there are some significant limitations in the current practice of the Driving Up Standards campaign that provide important lessons for effective global partnerships. Using criteria developed for evaluating the effectiveness of labor-community coalitions, Tattersall found that obstacles to global union collaboration can arise where there is a lack of clear-cut mutual interests, distinct differences in practice and organizing style between the two unions, and uneven partnership in decision making. Still, given the lack of cross-border organizing in the service sector, the global partnerships unit offers significant opportunities for future endeavors, where SEIU and other unions can build on this initiative to create more mutual partnerships and effective campaigns in the future.

In chapter 9 Dimitris Stevis and Terry Boswell address the opportunities and limitations that International Framework Agreements (IFAs) and other IFA-like global agreements provide unions when taking on large transnational corporations. As Stevis and Boswell explain, these global agreements are a fairly recent and primarily European phenomenon that many GUFs and European national unions see as their most significant accomplishments. Some even consider them to be the closest the labor movement has gotten to truly global negotiations with the world's largest transnational corporations. Those with a more critical view of IFAs, including many national union federations and national unions outside Europe, emphasize IFAs as unenforceable agreements that are almost entirely concentrated in European countries. At best IFAs can be one element in a multifaceted comprehensive cross-border campaign, but at worst they can be used by employers to co-opt or undermine the union campaign. Stevis and Boswell contend that the answer is to address the limitations of IFAs by making them truly global and enforceable and by also empowering GUFs to act more like real global unions, suggestions that are also emerging from the IUF's review of the effectiveness of IFAs.

Finally the last chapter, by Darryn Snell, looks at the true outlaws among the world's largest transnational corporations. These include firms that have been charged with direct involvement in a wide range of human rights violations in the Global South, such as mass executions, rape, torture, forced labor, forced relocation of indigenous populations, and active involvement in 
or direct support for military operations ranging from toppling governments to crushing rebellions. This group also encompasses those who are charged with more indirect involvement with human rights abuses because of their failure to do anything to correct or prevent the conflicts and human rights violations that are occurring around them. Snell looks first at how NGOs and trade unions have worked together to investigate and prove the extent of human rights abuses taking place and then at how they have held corporations accountable through lawsuits, shareholder actions, boycotts and divestment campaigns, and developing codes of conduct. As Snell points out, none of these are simple, because many companies that NGOs may target for a financially damaging lawsuit, a boycott, or divestment, may have large numbers of unionized facilities in Europe or North America or in other countries in the Global South that could suffer severe hardship if these campaigns were successful. But as Snell concludes, partnering with NGOs to stop these abuses cannot be optional for the global labor movement. As in the fight against apartheid, if unions do not put everything they have into a global challenge of these firms, then they have lost their moral standing.

\section{Building a Sustainable Global Network}

The third and final goal of the conference was to "lay the groundwork for building a sustainable global network of unions and academics to continue to work together to effectively engage transnational corporations worldwide." Certainly just holding the conference and allowing the connections to be made accomplished a big part of this goal, as does the conference website, which includes all the company research reports, video streaming of all the conference speeches, and copies of all the papers presented at the conference (see http://www.ilr.cornell.edu/globalunionsconference/). Yet in the end it is this edited book that the conference planners hope to have as the most lasting legacy of the conference. We hope that it will be read by researchers and strategic campaigners from unions and NGOs around the world to help them critically analyze how their organizations could more effectively work together to take on transnational corporations in their industry or regions. We hope that it will also be read by labor scholars across many disciplines to encourage more and better research in both cross-border campaigns and the changing nature, structure, and practice of transnational corporations. We also hope that it will be read by young people in the labor movement and in universities and colleges around the world and will inspire them to work with unions and NGOs as part of the global effort to stop the race to the bottom.

The lessons that can be learned from this book are the lessons that we hoped were learned from the conference itself. As Hassan Yussuff said in his closing 
speech, the simplest lesson of all is that "[w]e need to meet like this more often. This kind of critical, collective reflection among researchers, activists, union staff and leaders produces formal and informal exchanges that are valuable for action" (Yussuff 2006). Unions and academics wrestling with these same core issues must find ways to come together on a much more frequent basis and must make the effort to raise the funds so that the north-south connections that were initiated at the conference are no longer the exception but the norm.

We also desperately need more and better research from a much wider range of scholars, but even more important, we need more scholars to actively engage with the research issues raised by the themes of this conference. This includes more in-depth research focusing on every aspect of large transnational firms, as well as both quantitative and qualitative cross-cultural research on employer and union strategies in organizing and bargaining in the global environment. I issue this challenge knowing full well the risks that are entailed in conducting research on powerful transnational corporations. But these are risks that we as scholars must take if there is to be an informed challenge to the neoliberal agenda.

This book demonstrates how much further the labor movement needs to go in truly building a global labor movement. As Valeria Pugliano points out, unions in Europe are still in the nascent stages of understanding that they have more to gain as a united European labor movement than by putting their local interests first. Unions from the Global North, particularly the GUFs, also must understand that IFAs and cross-border campaigns that do not take into consideration the interests and concerns of workers in the Global South are doomed to failure.

Finally, unions can no longer afford to limit their cross-border activity to defensive actions. Strategies such as strategic corporate research, worker-toworker exchanges, global coalition building, and comprehensive campaigns need to become a constant in the organizing and bargaining relationship with these large transnational firms. Labor has an even greater capacity than capital to be globally connected because it can connect with workers at every level. Whether apparel workers in EPZ zones in Sri Lanka, dockworkers in Europe, or banana workers in Latin America, in the end, all the workers whose stories are told in this book took on capital and won by uniting, first with one another, then with other unions and NGOs, and then with the world. As Hassan Yussuff reminded us, "we need to make it an automatic reflex to appreciate that global capital has its weaknesses. Too often ... the strengths have been emphasized. The weaknesses and failings are real. The focus on them reminds us hope should always be more convincing than despair" (2006).

The chapters in this book make clear that unions have the capability to build the cross-border coalitions necessary to take on transnational corporations. 
The question is whether they are willing to make the fundamental ideological and cultural changes necessary to make this happen on a global scale. If they are, then maybe it will be five, not twenty years before Wal-Mart is no longer driving the global race to the bottom; before firms such as Exxon Mobil, CocaCola, Talisman, Caterpillar, and any number of large pharmaceutical companies will no longer be able to profess to be good corporate citizens in some countries and operate entirely outside the law in others. All of us who put so much work into the conference and into this volume did so because we believe that unions and their allies do have the capacity to change and become a global movement. But most important of all, we believe that with these changes, the balance of power, like the arc of history, will finally be tilting away from capital toward workers, their unions, and communities in both the Global North and Global South. 


\title{
1. BEATING GLOBAL CAPITAL
}

\author{
A Framework and Method for Union Strategic \\ Corporate Research and Campaigns
}

TOM JURAVICH

As unions in the United States struggle to survive in the face of the globalization of firms combined with unprecedented employer opposition to unions, it is clear that new approaches, strategies, and tactics are imperative. The ways of organizing and bargaining forged during the labor-management accord in the 1950s and 1960s-approaches that relied heavily on the law and administrative proceduralism - simply have no place in this new reality, given the withdrawal of corporations from the accord and growing employer intransigence, as workers in the United States now find themselves on a world stage. If labor in the United States has any hope of remaining a source of power for working people on the job and in their communities, it must find a way to pick up the gauntlet thrown down by global capital in this new environment.

One of the fundamental ways the labor movement in the United States is rising to this challenge is through strategic corporate research and the development of comprehensive strategic campaigns in both organizing and collective bargaining. Sometimes referred to as simply strategic or coordinated campaigns, or by the older nomenclature of corporate campaigns, this approach recognizes that to be successful, unions need to gain a comprehensive understanding of the firm and the industry in which it is situated. Only as a product of this kind of research and analysis can unions design the appropriate strategies and tactics to be successful, taking into account both how power flows through the firm and how vulnerabilities can be exploited. The comprehensive strategic campaigns

The author would like to thank Kate Bronfenbrenner, Darryn Snell, Teresa Healy, and two anonymous reviewers for their comments and suggestions, and Beth Berry for copyediting. 
that result go far beyond traditional organizing and bargaining and develop creative and complex processes that pressure firms in a multitude of ways.

Over the past two decades we have watched the maturation of strategic research and campaigns by unions in the United States. Indeed, it is difficult to identify a major union victory during the past decade that did not in some significant way employ strategic research and a comprehensive campaign. Ranging from the Service Employees International Union (SEIU)'s successful Justice for Janitors campaign in Los Angeles (Waldinger et al. 1998) to the International Brotherhood of Teamsters' victory at UPS (Witt and Wilson 1998) and the victory at Bridgestone/Firestone by the Steelworkers (Juravich and Bronfenbrenner 2003), unions in the United States have shown how they can win, and win big, using these approaches.

While this chapter is written from a U.S. perspective, it is important to note here that the use of strategic research and campaigns is not just a story about unions in the United States. Unions in the United States took a frontal attack by global employers; over the last three decades they have watched as entire industries were moved offshore and outsourced and an industrial relations system gutted. As we will see, over a decade of experimentation, U.S. unions began relying on strategic research and comprehensive campaigns to gain traction against the emerging global giants. Workers and their unions in the United States were not the only ones to feel the ravages of globalization, however, and these types of comprehensive campaigns are relevant responses not just for U.S.-based unions.

In fact, in many ways workers in the Global South have always been on the front lines in the struggles against global firms. Rooted in the legacy of colonialism, early transnational enterprises continued this oppression, spawning campaigns for workers' rights in the banana industry in the 1950s in Central America (see Frundt chapter 5) and for women textile workers in the "peace market" in Korea in the 1970s (Soonok 2003) and leading to the more recent struggles by Bolivian citizens to reclaim their water system (Schultz 2005). While rooted in social movements, a number of campaigns in the Global South are increasingly using sophisticated strategic research. For example, research by the Social Observatory, a nongovernmental organization (NGO) in Brazil, funded in part by the Brazilian labor movement, documented that children working in Brazilian mines produced materials for the British-based ICI (Goodwin 2006), and clandestine shops supplied apparel for a Dutch transnational (Social Observatory 2006). And while the social, political, and economic contexts are indeed quite different, there is a growing synergy between strategic research and comprehensive campaigns in the United States and throughout the Global South.

The situation in western Europe has historically been quite different. While their specific industrial relations systems differ, many countries provide institutional voice for unions on works council or similar structures, provisions shored up in European Union (EU) law. Historically, this has meant that 
labor-management relations have been considerably less adversarial than those in the United States. Given the presence of these institutions and European tradition, some have questioned the relevance of American-style strategic research and comprehensive campaigns for unions in the EU. Several factors, however, suggest that trade union practice in the EU may be changing.

The first is the very integration of the EU. While unions had national-based institutions in place, the question is how they dovetail with larger EU structures (Hyman 2005). As Valeria Pulignano writes in chapter 7 of this book, "[O]ne of the factors limiting the capacity of the labor movement to coordinate across borders is the difficulty in creating links between the European, the national, and the local levels of union structures." Her case study illustrates how this lack of coordination empowered General Motors' pitting of workers against one another across national boundaries. In contrast, Peter Turnbull (chapter 6) documents how dockworkers, in a sector with a long tradition of global solidarity, including in Europe, were much more effective in overcoming national barriers and mounting a successful European-wide crossborder campaign. Thus it remains to be seen how well traditional structures, now in flux as a result of EU integration, will constrain the behavior of global capital in Europe. It is in this context that European unionists are exploring the possibilities of strategic research and comprehensive campaigns.

Despite these successful campaigns and the growing reliance by unions in the United States and around the world on these methods, there is a surprising lack of information on strategic research and its use in the development of strategic campaigns. ${ }^{1}$ One of the pioneers in training corporate researchers, the former Food and Allied Service Trades (FAST) Department of the AFL-CIO, for many years published its Manual of Corporate Investigation (FAST 2006). More recently a number of unions, such as SEIU and American Federation of State, County and Municipal Employees (AFSCME), have provided basic guides to finding corporate information on the Internet. While these resources provide important sources of information, what is lacking is an overall research framework or primer for conducting strategic corporate research and applying it to strategic campaigns.

1 To some degree this lack of instructional materials by unions may be purposeful. As soon as these strategic campaigns started becoming successful, employers retaliated by filing lawsuits against unions for using them. For example, during the Ravenswood campaign by the Steelworkers, the employer filed charges under the Racketeer Influenced and Corrupt Organizations Act (RICO) against individual activists in the local union (Juravich and Bronfenbrenner 1999). The Steelworkers, along with several other unions, have been sued a number of times subsequently, with several suits hanging over the union for years at a time and employers using the deposition process to try to gain access to a wide range of union documents and information. Given this situation, unions have been reticent about preparing materials that could help them educationally but could be used against them in a court of law. 
Similarly, the scholarly community has focused little attention on strategic research and campaigns. While there is some research about specific strategic campaigns (Brisbin 2002; Franklin 2002; Juravich and Bronfenbrenner 1999; Waldinger et al. 1998; Hickey 2004; Quan 2006; Witt and Wilson 1998), there have been few efforts to examine the theory or methods of strategic corporate research. The last issue of a journal dedicated to strategic research and campaigns was the 1993 issue of the Labor Research Review (1993).

This chapter aims to fill this gap by providing a basic framework for conducting strategic corporate research, as well as describing how this research can be applied to the development of comprehensive campaigns in organizing and bargaining. The model is designed to be applicable to a wide variety of employers and can be used by trade unionists and their allies at a number of different levels. Before we begin exploring this model, it is important to step back and place comprehensive campaigns in a larger historical framework. As important as the techniques of corporate research are, we cannot understand them thoroughly without also exploring the evolution of comprehensive strategic campaigns.

\section{Corporate Power and Union Forms of Resistance}

While it is tempting to look at comprehensive campaigns as something entirely new, in many ways they are the latest adaptation by labor to the changes in corporate structure and practice. If we look back at the history of the labor movement around the world, I would argue that labor has been successful when it develops forms of resistance that take into account how employers are structured and how they operate in the context of the state. While the recent development of comprehensive strategic campaigns is indeed innovative, these campaigns belong to a long line of strategic thinking by the labor movement.

While we could trace the evolution of forms of resistance in a number of different countries, table 1.1 outlines the development of union strategies and tactics and their relationship to corporate structure in the United States by examining four employers over four different time periods. We begin in 1912 in Lawrence, Massachusetts, with the American Woolen Company. American Woolen owned four of the major textile mills along the canals in Lawrence, a planned New England city on the banks of the Merrimack River. As was common in the textile industry in the later part of the nineteenth century and the early part of the twentieth century, the mills were single operations that served regional markets. Run by William Wood, American Woolen was what we would think of today as a limited partnership (Watson 2005, 23).

In this first part of the twentieth century, the financial community had yet to establish the kinds of credit systems that would allow firms to borrow funds. This led to boom-and-bust cycles in the New England textile mills, as well as in 
TABLE 1.1.

A historical analysis of corporate structure and successful forms of union resistance in the United States

\begin{tabular}{|c|c|c|c|c|}
\hline & $\begin{array}{l}\text { American } \\
\text { Woolen, } \\
\text { Lawrence } \\
(1912)\end{array}$ & $\begin{array}{l}\text { GM Flint } \\
\text { (1937) }\end{array}$ & U.S. Steel (1965) & $\begin{array}{l}\text { Bridgestone/ } \\
\text { Firestone (1996) }\end{array}$ \\
\hline \multicolumn{5}{|c|}{ Corporate Stucture } \\
\hline Production & Single plant & Multiple plants & Multiple plants & Global plants \\
\hline Distribution & Regional & National & Some international & Fully inter- \\
\hline Financing & Partnership & $\begin{array}{l}\text { Early U.S.- } \\
\text { based } \\
\text { corporation }\end{array}$ & $\begin{array}{l}\text { Mature U.S.-based } \\
\text { corporation }\end{array}$ & $\begin{array}{l}\text { national } \\
\text { Global corpor- } \\
\text { ation }\end{array}$ \\
\hline Role of the state & $\begin{array}{l}\text { No institutional } \\
\text { involvement } \\
\text { in labor } \\
\text { issues }\end{array}$ & $\begin{array}{l}\text { Increasing } \\
\text { militancy } \\
\text { Pressure on } \\
\text { state }\end{array}$ & $\begin{array}{l}\text { Heavily in } \\
\text { tripartite IR } \\
\text { system }\end{array}$ & $\begin{array}{l}\text { Undermining of } \\
\text { extant IR } \\
\text { system }\end{array}$ \\
\hline $\begin{array}{l}\text { Union form of } \\
\text { resistance }\end{array}$ & Simple strike & Selective strike & Pattern bargaining & $\begin{array}{c}\text { Comprehensive } \\
\text { campaign }\end{array}$ \\
\hline
\end{tabular}

the larger economy. This meant that American Woolen, like every other firm, depended on a rapid turnover of its inventory to generate the cash to keep the company operating.

In January 1912, the largely immigrant workforce of women, organized by the Industrial Workers of the World (IWW), walked out of the Lawrence mills. In what many consider the first modern strike in the United States, the women marched and paraded through the streets of Lawrence, keeping workers from returning to work and effectively shutting down production (Juravich, Hartford, and Green 1996). By late March, the company, near economic ruin, capitulated to the strikers' demands.

While there is a great deal more to the story of what has been called the "Bread and Roses" strike, what is important to our discussion here is that American Woolen's structure meant that the company could be brought to its knees by the withdrawal of labor in a simple strike-a strategy used throughout the United States and around the world in the later part of the nineteenth and the early part of the twentieth century. This was a local strategy, one often based in craft unionism or unions at the local level. Without the ability of the company to shift production or to borrow funds, a simple work stoppage was an incredibly powerful weapon for labor. While there was no institutional role for the state in labor industrial relations, local law enforcement would often play a pivotal role in these disputes.

Corporate structure changed, however, and along with it labor's form of resistance had to change, too. In the opening chapters of John Steinbeck's The Grapes of Wrath, Tom Joad, the main character of the novel, returns to his home to find that his family's farm has been bought out by a large corporation 
and the family is moving west. As he goes out to the old place, he sees a large tractor tearing down the family's farm and barns. He threatens to kill the tractor driver to stop the destruction. The driver responds, "Joad, they'll just hang you, but before you're hung, there'll be another guy on the tractor, and he'll bump the house down. You're not killing the right guy" (Steinbeck 1939, 52).

Over the next several paragraphs, Joad suggests that he should instead kill the guy giving the orders or the bank president and so on. But with each suggestion the driver responds that it won't stop the destruction of the farms, valiantly trying to help Joad understand the nature of a modern corporation. This was not an operation controlled by one man, such as those run by mill owners of an earlier era, that could be stopped by the shooting of one man. Firms had changed, and union tactics would have to change as well if they were to be successful in this new milieu.

General Motors was one of the early corporations that emerged in the 1930s. Unlike American Woolen, it had a number of plants, many performing the same function, and serving not a regional but a national market. And, while financing was not as sophisticated as it is today, the corporate structure did allow for more cash flow to weather short-term downturns. Given these changes in corporate structure, the simple strikes used by the IWW in Lawrence were no longer appropriate. If the United Auto Workers (UAW) struck an individual plant during its organizational drive, the work would have simply been shifted to another plant, the workers fired, and the union's drive set back on its heels. This happened throughout the 1930s and 1940s as workers and their unions still clung to the strategies of the earlier era, struggling futilely against different kinds of firms.

In their campaign against General Motors, the UAW developed a strategy that anticipated this new corporate structure. From their research they knew that Fisher Body Plants 1 and 2 were the major suppliers of body parts for Chevrolets and Buicks (Lichtenstein 1995, 76). The union targeted these key plants and was planning a strike for January, after newly elected Michigan governor Frank Murphy's inauguration. However, when rumors spread that crucial dies were soon to be moved, local activists jumped the gun and initiated the famous sit-down strike that was fundamental to the UAW's wresting union recognition from General Motors (Zieger 1995, 50).

While the sit-down feature of this strike was crucial, what is also significant about the Flint strike is that it was not a simple strike like the one at Lawrence but a selective or tactical strike that took into account the new corporate form. By targeting the Fisher plants, the UAW understood the vulnerabilities of GM and was able to take full advantage of them. At the same time, the role of the state in industrial relations was changing. Under pressure from growing labor militancy President Roosevelt had provided union recognition in section 7 of the National Industrial Recovery Act of 1933 (NIRA). By the time of the strike 
in Flint, the more comprehensive Wagner Act was still in the courts, but the government was beginning a much deeper involvement in labor-management relations.

Corporations in the United States continued to mature, and in the wake of the involvement of the U.S. labor movement in tripartite agreements during World War II, an industrial relations system arose (Kaufman 1992). For the first and only time in U.S. history, an accord emerged between labor and management, and a complex set of state-supported procedures was put in place in an effort to level the playing field between the two parties. At this point there was an explosion in the length of union contracts, far beyond the single page that marked the initial agreement between GM and the UAW, and the institution of complex, multistage grievance and arbitration processes.

United States Steel emerged as one of the leading U.S. firms during this period, and it represented a further evolution of the corporation. Like GM it had a number of plants across the United States, distributing not only to the entire country but internationally as well (Hoerr 1988). United States Steel, along with the United Steelworkers of America (USWA), developed a complex set of rules governing the workplace, including a private arbitration system. The firm experienced rapid growth during the 1950s and 1960s and, with a command of the U.S. market, was hugely profitable. The evolution of both corporate law and banking further strengthened its economic security.

Against such a stable firm, the labor movement was losing the power of selective strikes. Given the labor-management accord and the legal and regulatory framework in place, the Steelworkers, and much of the labor movement in the United States, moved instead in a different direction. In the steel, auto, and many other basic industries, the labor movement moved to pattern bargaining, negotiating not with just one firm but with the major firms in an entire industry.

Until the mid- to late 1970s unions were able to use pattern bargaining to deliver increasingly stronger contracts to union members in these core industries. It is, however, important to note here that these adaptations marked a significant departure for labor, constituting forms of acquiescence to the new industrial relations system rather than the forms of resistance of earlier eras. As long as the accord held, the system delivered, but by the late 1970s, when the U.S. economy came to a standstill, the accord began to unravel as employers such as International Paper and Phelps-Dodge took off their gloves. The legal and procedural framework that had once brought a measure of justice and security to workers in the United States was now an empty shell, openly ignored by the U.S. government. It became clear that labor would need to return to its past and once again develop new forms of resistance that made sense, given the new corporate order.

Confronted with these new realities-plant closings, outsourcing, a new corporate adversarialism, and the failure of the postwar industrial relations 
system - the late 1970s and early 1980s were a time of great loss of membership in the labor movement in the United States. But it was also a time of great experimentation, as labor began to explore new approaches.

One important innovation was the work of Ray Rogers in the late 1970s, with his development of the first corporate campaign at J.P. Stevens, a notorious antiunion firm located largely in the south. The textile workers' union had been unsuccessful for years in trying to break into Stevens, in what were essentially company towns. Rogers, a young union staffer, came up with an important alternative. Instead of going head to head against the company in its strongholds, the union would bring pressure on the firm indirectly by pressuring members of the board of directors. By targeting key board members, Rogers brought Stevens to the bargaining table, doing in a matter of months what on-the-ground organizing had been unable to accomplish for years (Pauly and Walcott 1978, 58).

During the 1980s, unions also reached back to their roots in the communities where they had been born and began experimenting with building community coalitions and community campaigns. One of the best examples was the campaign run by the United Electrical Workers (UE) at Morse Cutting Tool in New Bedford, Massachusetts (Swinney 1982). Morse had been bought by the behemoth Gulf and Western, which was threatening to shutter the facility. The UE worked tirelessly with the community in this small fishing and industrial city on the Massachusetts coast. The campaign culminated with the mayor of New Bedford threatening to seize the plant through the power of eminent domain. Gulf and Western capitulated, the facility sold, and the jobs remained in New Bedford.

In addition to these early corporate and community campaigns, labor innovated in a number of areas, including running what were called inside campaigns. At Moog Automotive, under the leadership of UAW staff representative Jerry Tucker, workers stayed on the job and worked without a contract and were able to exert tremendous pressure on the production process, forcing a settlement (Metzgar 1985). This was part of a return to local militancy by trade unionists wanting to play more of a role in their future through direct action rather than waiting for the wheels of a largely dysfunctional industrial relations system to slowly turn.

While each of these tactics held tremendous promise, the wreckage of the 1980s demonstrated that none of these approaches was the silver bullet labor was hoping for. Not all companies had boards that were as highly leveragable as the Stevens board, not all companies were located in places where community pressure could be generated, and, in areas where community pressure could be counted on, firms were not as vulnerable to that kind of pressure as Gulf and Western was in New Bedford. In-plant strategies also required tremendous worker discipline and solidarity and also depended on corporate 
commitment to that specific site or facility. If either the work site or the workers themselves were expendable, then even the most militant and united inside action would be rendered entirely ineffective.

By the beginning of the 1990s, the lessons were clear. There would be no single route to labor's revival, and, in fact, campaigns that focused on only one issue or approach were doomed to fail. Instead, what began to emerge was that, given the changes taking place in corporate structure with the emergence of global firms, only multifaceted campaigns - campaigns that brought leverage on employers in multiple areas - would succeed. Perhaps the best example was the Steelworkers campaign against Japanese-owned tire giant Bridgestone/Firestone (BSFS).

Table 1.1 shows that production at BSFS was truly global, with plants located around the world. Distribution was global as well, and the Steelworkers were up against a firm that looked very different from U.S. Steel. Given these facts, the older approaches of selective strikes and pattern bargaining were no longer applicable.

The Steelworkers used lessons learned from their seminal victory in the twenty-two month lockout at Ravenswood Aluminum (Juravich and Bronfenbrenner 1999) and built a comprehensive strategic campaign at Bridgestone/Firestone that was anything but one-dimensional. It focused on major stockholders and lenders, mounted an ambitious end-user campaign pressuring consumers not to buy BSFS tires, built broad alliances with religious and civil rights leaders, and, as part of an ambitious international campaign, sent worker delegations to Japan (Juravich and Bronfenbrenner 2003).

As in the Ravenswood campaign, the basic modus operandi was to constantly escalate the campaign, starting new fronts against the company as other fronts were waning. In the words of former USWA president George Becker,

The last thing I wanted the company ... to think of before [they] went to bed at night, Monday, Tuesday, Wednesday, Thursday, Friday, Saturday and Sunday night ... is all the problems and difficulties we caused them that day. And the first thing I wanted them to think of when they wake up is, "Oh Christ, I've got to go out and face them sons of bitches again." ... We had to get them thinking about the Steelworkers continually, every day ... if we let an hour go by that our name didn't cross their minds for some reason or another, then we were failing. (Juravich and Bronfenbrenner 1999, 132)

Using this approach, the Steelworkers were able to win at BSFS, demonstrating the power of strategic research and comprehensive campaigns against even global giants. This kind of multifaceted strategic campaign was precisely the form of resistance needed in this new corporate environment. Key to the victory here, as well as the one in Ravenswood, was the involvement 
of rank-and-file workers. Early corporate campaigns tended to marginalize rank-and-file workers, which was problematic. In fact, neither of these campaigns could have been won without the rank-and-file militancy that kept scabs out of the plants and kept the heat on the employer locally (Juravich and Bronfenbrenner 1999; Bronfenbrenner and Juravich 2001). Yet it is also important to note that, against global giants like BSFS, local militancy alone was not enough. We saw this in a number of battles that unions lost in the 1980 s and 1990s. Workers stood tall, kept scabs out, and engaged in courageous actions, but without some larger strategic campaign to leverage the firm, the local militancy alone, which might have been enough at Lawrence, was no longer sufficient.

\section{A Model for Strategic Corporate Research}

Tracing the evolution of strategic campaigns provides an important foundation to lay out a model and framework for conducting strategic corporate research. ${ }^{2}$ Several things have become clear. First, strategic corporate research is not just random information gathering on employers. This is not just research for its own sake but research directed both at understanding how power flows in firms and at identifying vulnerabilities and potential points of leverage. Second, strategic corporate research is not simply about "digging up dirt" on employers to use in more traditional bargaining and organizing campaigns. As we have seen from our analysis of the evolution of corporate structure, gathering dirt to use in old-style campaigns has little chance for success against today's global giants. Strategic research needs to be the first step in developing the kinds of multifaceted strategic campaigns that are necessary to win today.

In reviewing the small amount of material on corporate research, the only common analytical tool is what has been called a power analysis or web analysis. It typically involves placing the target firm in the center of a page and then brainstorming any and all connections to top management, board members, customers, community groups, and the like, and placing them in a large circle around the firm linked by arrows.

While it is a powerful brainstorming tool for initial thinking about a corporation, the web analysis has a number of limitations. First, it does not distinguish between what is inside the firm and what is outside. Management is inside the firm, while environmental groups are outside. This is important be-

2 This framework and materials were developed with the consultation of Kate Bronfenbrenner of Cornell University and Keith Mestrich, formerly of the AFL-CIO and now with UNITE HERE. I was fortunate to have worked with them for several years in helping to develop the curriculum for and teach in the Cornell University/AFL-CIO Strategic Corporate Research Summer School. 